\title{
まちづくり協議会が主体となる 「船カフェ」の実践
}

\section{PRACTICE OF "FLOATING CAFE" BY THE COMMUNITY BOARD}

細田 渉— $* 1 \quad$ 澤野 朋— -1
志村秀明—2

キーワード :

運河ルネサンス, 水上カフェ, まちづくり協議会, 水域活用, 社会実験, 協働

Keywords:

Canal Renaissance, Floating cafe, Community board, Using water area, Pilot program, Partnership

\section{Wataru HOSODA — $* 1$ \\ Hideaki SHIMURA — $* 2$ \\ Tomo SAWANO $-* 1$}

The purpose of this paper is to report on the result of "Floating Cafe" pilot project that community board had practiced, and to analyze the sufficient conditions for practice of "Floating Cafe".

The conclusions are; 1) "Floating Cafe" attracted wide range of customers, and gave positive consciousness for them. "Floating Cafe" will be community business. 2) The sufficient conditions are; a management agreement which specify a community board can use a floating pier is concluded; a community board include organizations which have retail associations, cruise companies, and experts like universities; members of a community board have collaboration each other.

\section{1.はじめに}

\section{1 研究の背景と目的}

我が国には運河・河川といった水域が多く存在している。しかし、 それらは物流が舟運から陸運となり十分に活用されていない。都市 の魅力向上のためには、水域の活用が望まれる ${ }^{1)}$ 。近年、東京都で は「運河ルネサンス注 11 」によって、港区芝浦地区、品川区品川浦・ 天王洲地区、勝島・浜川・鮫洲地区、中央区朝潮地区、江東区豊洲 地区で水域活用を促進しようと寸る活動が行われている。

ところで地域の中の様々な主体が連携する活動が増えている。そ の中で地区の住民組織、企業、大学、自治体等の様々な主体が連携 するまちづくり協議会は、市民活動を長期間にわたって下支えする 主体として重要な役割を持ち得ると言えよう。このようなまちづく り協議会が主体となる水域活用の手法は、様々な地域で実践できる 可能性がある。

本報告は以上のような視点から、まちづくり協議会が主体となる 水域活用の手法を開発・普及することを主眼としている。

そしてここでは、江東区豊洲地区において、住民組織、企業、NP0、 大学等が会員である「豊洲地区運河ルネサンス協議会」（以下：運ル ネ協議会) が実施した船舶を用いての水上カフェ(以下:「船カフェ」) 社会実験を対象として、その結果について報告すると共に、その実 施までの経緯や実施体制を分析し、「船カフェ」が実施可能となる十 分条件を明らかにする。

\section{2 既往の取り組みと報告}

広島市京橋川で実施された河岸緑地でのオープンカフェ ${ }^{2)}$ や阪 市北浜テラスの社会実験 ${ }^{3)}$ 等で水辺空間の利活用の事例と報告はあ る。しかし、まちづくり協議会が一定期間、水域を占用し「船力フ エ」を実施した報告はない。

なお本報告では、運ルネ協議会をまちづくり協議会の一種と位置 づける。

\section{3 研究の方法}

「船カフェ」は豊洲運河船着場（以下：船着場）に繋留した船舶 で実施した。その目的は、(1)船着場を有効活用し、ふれあいの場と する。(2)水辺・運河への人々の関心を高める。(3)船着場・運ルネ協 議会の認知度を高める。の 3 つである。

まず「船カフェ」を実施可能とする基本的条件を明らかにするた めに、船着場整備までの経緯を提示する。次に、実施した「船カフ

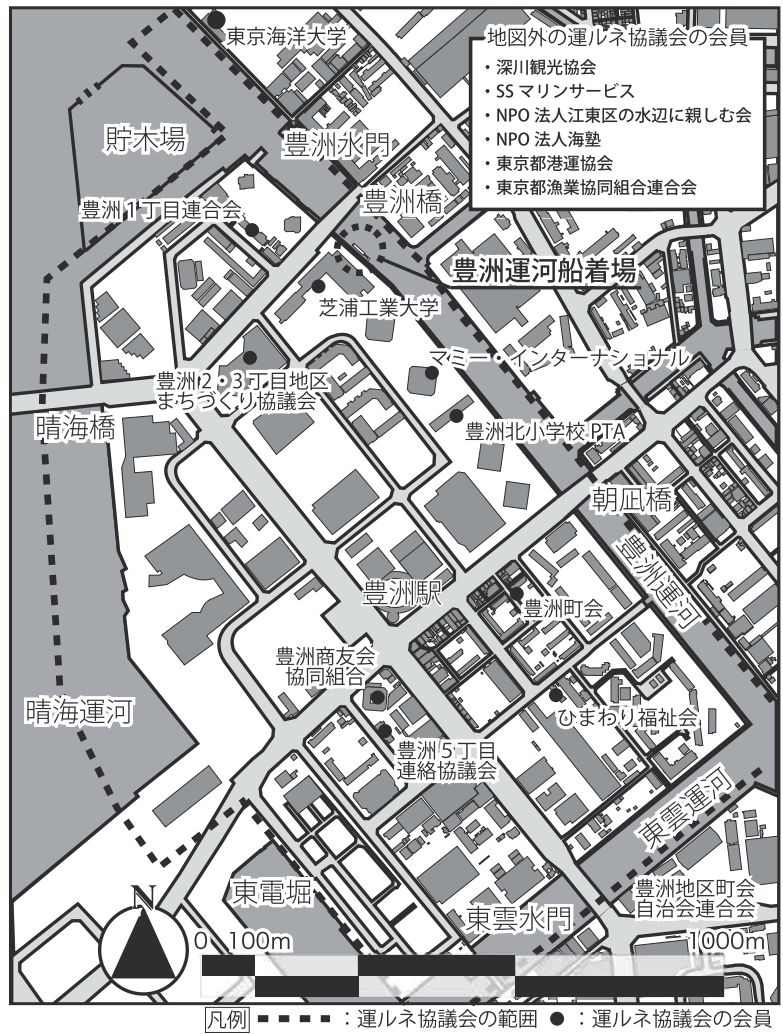

図 1 豊洲地区

\footnotetext{
芝浦工業大学大学院理工学研究課建設工学専攻 修士課程

( ₹ 135-8545 東京都江東区豊洲 3-7-5)
}

芝浦工業大学工学部建築学科 教授・博士 (工学)

Graduate Student, Shibaura Institute of Technology

Prof., Dept. of Architecture, Shibaura Institute of Technology, Dr. Eng. 
エ」の概要と結果を報告する。そして、「船カフェ」を実施可能とす る十分条件を明らかにするために、「船カフェ」準備段階と実施にお ける運ルネ協議会会員の作業と役割分担を明らかにする。

調査にあたり、協議会・準備段階の会合・実施中の記録注 2) 参照 した。また、「船カフェ」実施に関わった団体に対してヒアリング調 查注3)を行った。さらに「船カフェ」来客者へのアンケート調查注 ${ }^{4)}$ を行った。

\section{4 豊洲地区の概要}

豊洲地区の地図を図 1 に示す

江東区臨海部に位置する、1921 年から 1932 年に埋められた埋立 地で、豊洲運河、睛海運河、東雲運河に囲まれている。ほとんどが 造船所といった工場であった。その後、1988 年に地下鉄有楽町線豊 洲駅が開通し、1997 年からの再開発により高層マンションや大規模 商業施設が建設されている。

なお運ルネ協議会は、豊洲 1 丁目から 5 丁目を範囲としている。

\section{2. 船着場の整備までの経緯}

本章では、運ルネ協議会の設立、船着場の整備経緯とその後の活 動について提示する。船着場整備前後の経緯を表 1 に示寸。

\section{1 運ルネ協議会の設立}

運河ルネサンス地区指定に向け、2006 年から「連絡会」が開催さ れたが進展はなかった。2007 年 11 月には芝浦工業大学 (以下 : 芝工 大)の学生が学園祭に合わせて仮設の船着場を設置して「豊洲運河リ バークルージング」を企画・実施した。このイベントをきっかけに 水域活用の気運が高まり、2008 年 2 月に「連絡会」が開催され、運 ルネ協議会の設立に向けた準備会を開始寸ることになった。2008 年 中に 5 回の「設立準備会」が開催され、同年 11 月には、「江東水辺 のまちづくりフォーラム」が行われた。

そして 2009 年 3 月に運ルネ協議会が設立した。運ルネ協議会の会 員を表 2 に示す。芝工大内に事務局を置き、「豊洲地区町会自治会連 合会」を会長として、住民組織、商店会、NP0 法人、大学、小学校 PTA、観光協会、クルージング業者等の団体で構成している。会員は、

\section{表 1 船着場整備前後の経緯}

\begin{tabular}{|c|c|c|c|}
\hline \multicolumn{2}{|c|}{ 目付 } & 会合 & \multirow[t]{2}{*}{ イベント } \\
\hline 2006年 & 3月31日 & 運河ルネサンス豊洲地区連絡会(第1回) & \\
\hline \multirow{2}{*}{ 2007年 } & 3月26日 & |運河ルネサンス豊洲地区連絡会(第2回) & \\
\hline & 11月24日 & & 豊洲運河リバークルージング(※1) \\
\hline \multirow{7}{*}{ 2008年 } & 2月15日 & |運河ルネサンス豊洲地区連絡会(第3回) & \\
\hline & 3月17日 & 第1回豊洲地区運ルネ協議会設立準備会 & \\
\hline & 5月 9日 & 第2回豊洲地区運ルネ協議会設立準備会 & \\
\hline & 7月 8日 & 第3回豊洲地区運ルネ協議会設立準備会 & \\
\hline & 9月29日 & 第4回豊洲地区運ルネ協議会設立準備会 & \\
\hline & 11月 2日 & & 「江東」水辺のまちづくりフォーラム(※2) \\
\hline & 12月 8日 & 第5回豊洲地区運ルネ協議会設立準備会 & \\
\hline \multirow{4}{*}{ 2009年 } & 3月 1回 & \multicolumn{2}{|c|}{ 「運ルネ協議会」設立 } \\
\hline & 3月 & \multicolumn{2}{|c|}{ 「キャナルウォーク」開放 } \\
\hline & 7月25日 & \multicolumn{2}{|r|}{ 打ち水大作戦 $(※ 3)$} \\
\hline & & \multicolumn{2}{|c|}{ 「潮風の散歩道」開放 } \\
\hline \multirow{4}{*}{ 2010年 } & 3月 & \multicolumn{2}{|c|}{ 「豊洲運河船着場」整備完了 } \\
\hline & & & \\
\hline & 3月27日 & & 江東水彩都市づくりフェスタ $(※ 4)$ \\
\hline & \multirow{2}{*}{\multicolumn{3}{|c|}{ 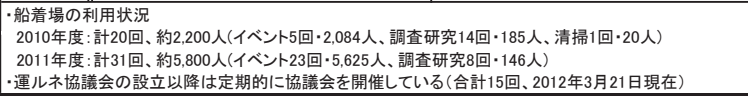 }} \\
\hline 2011年 & & & \\
\hline \multicolumn{4}{|c|}{ 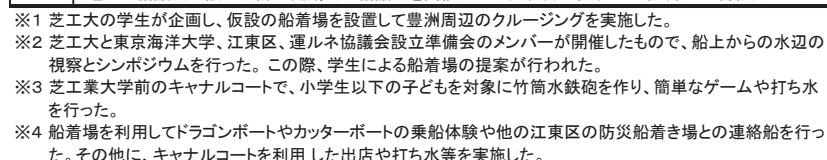 } \\
\hline
\end{tabular}

表 2 運ルネ協議会の会員

\begin{tabular}{|c|c|c|}
\hline & 会員名称 & 備考 \\
\hline 1 & 豊洲地区町会自治会連合会 & 協議会会長,住民組織 \\
\hline 2 & 豊洲町会 & \multirow{3}{*}{ 住民組織 } \\
\hline 3 & 豊洲1丁目連合会 & \\
\hline 4 & 豊洲5丁目連絡協議会 & \\
\hline 5 & 豊洲2·3丁目まちづくり協議会 & 企業団体 \\
\hline 6 & 豊洲商友会協同組合 & 商店会 \\
\hline 7 & NPO法人 江東区の水辺に親しむ会 & 江東区を中心に活動 \\
\hline 8 & NPO法人 海塾 & 港区を中心に活動 \\
\hline 9 & 芝浦工業大学 & 協議会事務局、2006年豊洲キャンパス開校 \\
\hline 10 & 豊洲北小学校PTA & 2007年に開校した小学校のPTA \\
\hline 11 & 社会福祉法人 ひまわり福祉会 & \multirow{2}{*}{ 保育施設 } \\
\hline 12 & マミー・インターナショナル & \\
\hline 13 & 深川観光協会 & 門前仲町を拠点 \\
\hline 14 & 東京都漁業協同組合連合会 & 豊洲周辺の業者が参加 \\
\hline 15 & SSマリンサービス & クルージング業者 \\
\hline
\end{tabular}

助言者: 東京海洋大学、江東区都市整備部、東京都港湾局、東京都港運協会

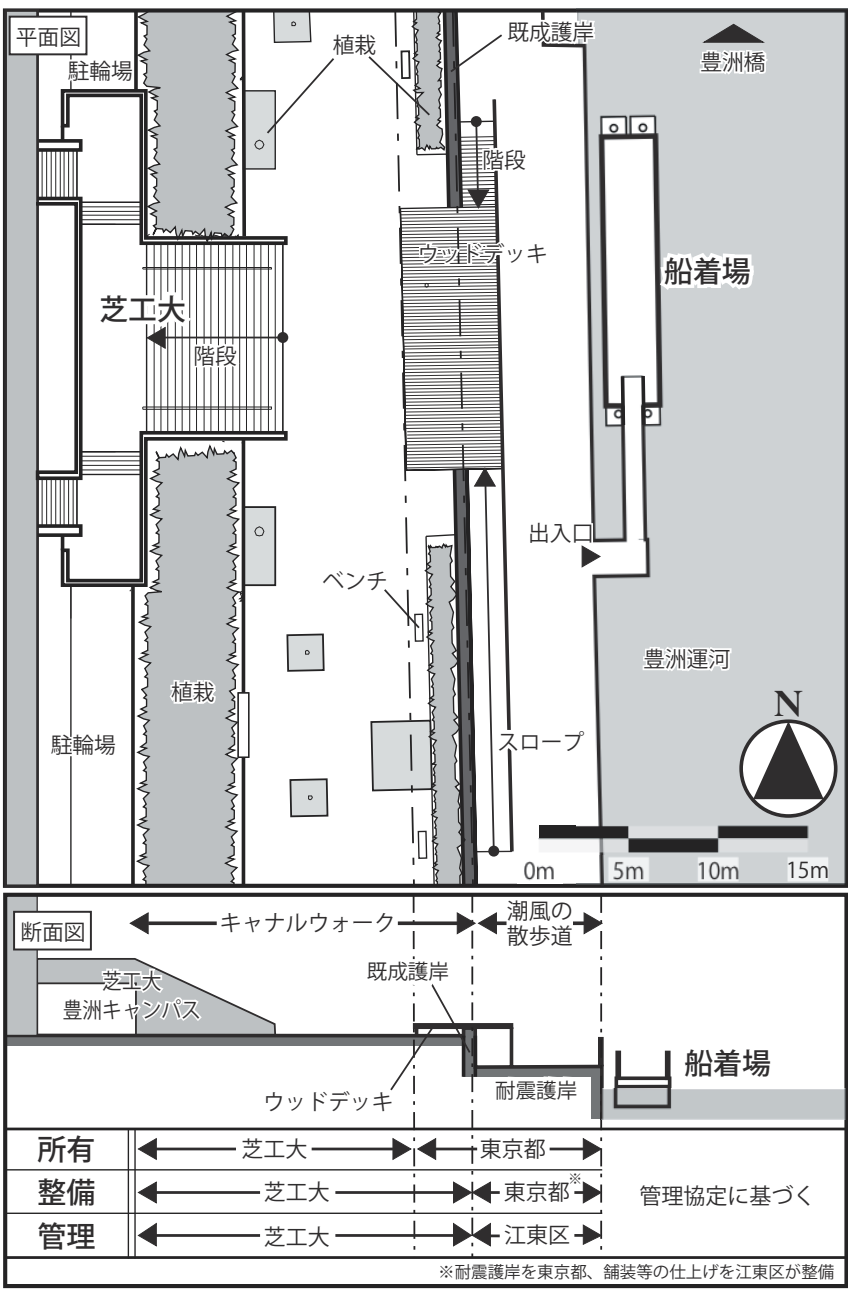

図 2 船着場とその周辺

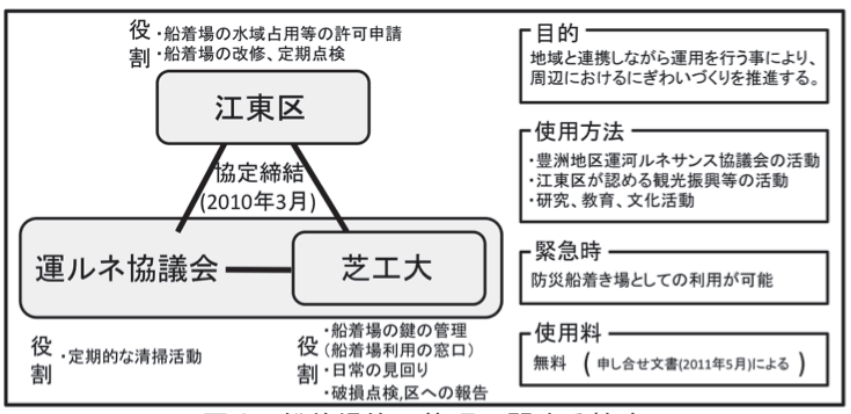

図 3 船着場等の管理に関する協定 
2012 年 2 月現在 15 団体である。これらの団体の位置を図 1 に示寸。

\section{2 船着場の整備}

船着場とその周辺の状況を図 2 に示す。

運ルネ協議会の設立と並行し、2009 年 3 月には豊洲運河沿いの「キ ヤナルウォーク」が芝工大等によって整備・解放された。そして「潮 風の散歩道」が江東区によって整備・解放された。その後、2010 年 3 月に江東区が浮き栈橋型の船着場を整備し、芝工大が地域貢献の 一環として、その周辺整備を行った注5)。

その際に、図 3 に示す「船着場等管理に関寸る協定書」（以下：管 理協定)を江東区、運ルネ協議会、芝工大の三者で締結した。

\section{3 小結}

豊洲地区の住民組織等からなる運ルネ協議会が設立し、主体的に 活動していることで船着場が整備された。

芝工大が船着場の利用の空口となること、「運ルネ協議会の活動」 「調查・研究・文化活動」等で船着場を無償で使用できることを定め た管理協定が締結されたことで、運ルネ協議会が様々な活動で船着 場を使用できることになった。

\section{3.「船カフェ」の概要と結果}

本章では、実施した「船カフェ」の概要と結果について提示する。

\section{1 「船カフェ」の概要}

「船カフェ」の配置を図 4 に、内容を表 3 に示す。

「船カフェ」では、船内の㕑房とテーブルを使用し、パン、焼き菓 子、ケーキ、ソフトドリンク、アルコール類の販売を行った ${ }^{\text {主 }}$ 。販 売物は全てテイクアウト可能であった。客席は、1 階船内に 16 席、 1 階デッキに 6 席程度、 2 階デッキに 17 席、合計 39 席程度であっ た注 7 。

「船カフェ」は 2011 年 4 月 14 日から 28 日 (以下: 春)、2011 年 8 月 6 日 (以下: 夏)、 2011 年 11 月 4 日から 6 日と $9 \cdot 10 \cdot 16 \cdot 17$ 日 (以 下: 秋)の 3 期間で実施した。

春は、「平時の社会実験」として、2 週間継続して実施した。

夏は、「地域イベント時の社会実験」として、運ルネ協議会が主催 の一員である「豊洲水彩まつり」に出店して実施した。「船カフェ」 以外に、春アンケートで要望があったクルージングを別の船舶で実 施し、さらに学生が企画した学生による音楽の生演奏 (以下 : 音楽演 奏)を実施した。また潮風の散歩道でテントを使用し、ドリンクの販 売を行った。

秋は、 4 日から 6 日 (以下: 秋前半) と $9 \cdot 10 \cdot 16 \cdot 17$ 日 (以下: 秋 後半)に分けて実施した。秋前半は、「学園祭と同時開催の社会実験」 として、実施した。夏に引き続き好評であったクルージングを別の 船舶で行い、水辺と船内で音楽演奏を行った。秋後半は、「日照時間 が短く寒い時期の平時の社会実験」として、実施した。「船カフェ」 とクルージングを一艇で実施した。

\section{2「船カフェ」の結果}

「船カフェ」の来客数・売上を表 4 に示寸。

来客数は、春では、計 13 日間で合計 1,961 人、 1 日平均 150 人で あった。週末に多く、日曜日は 280 人以上であった。天気が雨だと 激減し、4月 23 日は 32 人であった。夏では、1 日で 658 人と多か った。秋では、計 7 日間で合計 717 人、 1 日平均 102 人と少なかっ た。春、夏、秋を通して計 21 日間で合計 3,336 人、1 日平均 177
人であった。夏は、イベントとの相乗効果で来客数が多くなり、秋 は、日照時間が短く気温が低くなったため来客数が減少したと考え られる。

「船カフェ」の収支結果を表 5 に示す。収支は、春では、売上が約 100 万円であり、船代が 16 万円であったため、利益は約 9 万円であ った ${ }^{8)}$ 。夏では、売上が約 19 万円であり、人件費がかからなかっ たこと、また船代が豊洲水彩まつり全体の支出であったため、東北

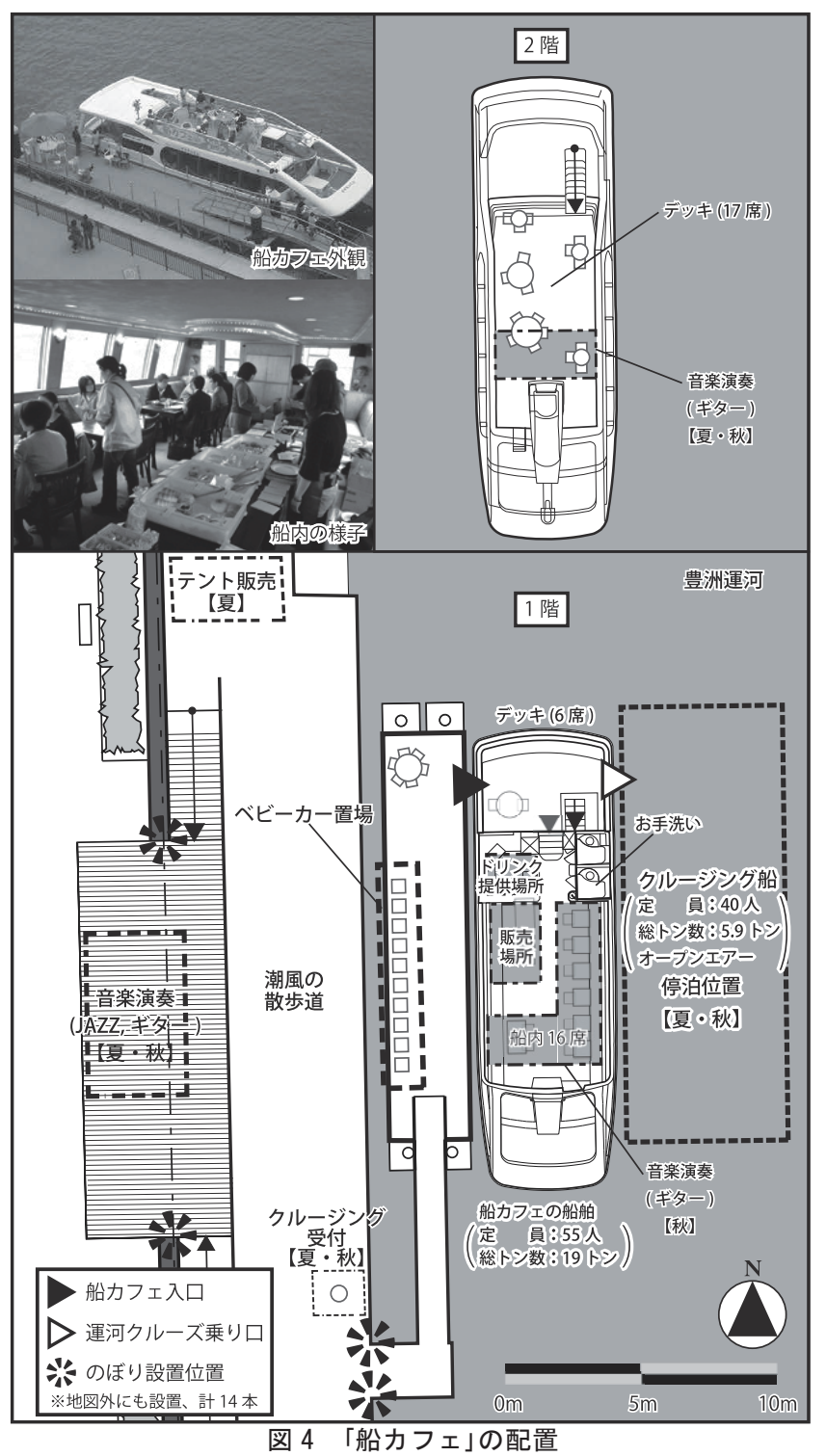

表 3 「船カフェ」各回の内容

\begin{tabular}{|c|c|c|c|c|c|}
\hline \multirow{3}{*}{ 日時 } & \multirow{3}{*}{ 販売物 } & \multicolumn{3}{|c|}{ 船着場周辺 } & \multirow{3}{*}{ 芝エ大 } \\
\hline & & \multicolumn{2}{|c|}{ 水上 } & \multirow{2}{*}{ 水辺 } & \\
\hline & & 船カフエ & クル & & \\
\hline \begin{tabular}{c|} 
春 \\
4 月14 28日 \\
10:00 16:00
\end{tabular} & 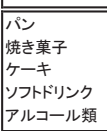 & $\begin{array}{l}- \text { 楽器演奏 } \\
\text { (初日のみ) } \\
\text { ·アンケート調査 }\end{array}$ & & & $\begin{array}{l}\text { 地方統一選挙 } \\
\text { (4月24) }\end{array}$ \\
\hline \multirow{2}{*}{\begin{tabular}{|l|}
\multicolumn{1}{|c|}{ 夏 } \\
8月6日 \\
10:00 16:00
\end{tabular}} & \multirow{2}{*}{ 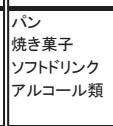 } & \multicolumn{3}{|c|}{ 豊洲水彩まつり } & -納涼祭 \\
\hline & & $\begin{array}{l}\text { ·音楽演奏 } \\
\text { (ギター) } \\
\text { ·アンケート調查 }\end{array}$ & $\begin{array}{l}\text { ·クルージング } \\
\text { ·音楽演奏 } \\
\text { (ギター) }\end{array}$ & $\begin{array}{l}\cdot \text { ·テト販売 } \\
\cdot \text { ·音楽演奏 } \\
\text { (ギター) }\end{array}$ & \\
\hline \begin{tabular}{|c|} 
秋前半 \\
11 月 $4 \cdot 5 \cdot 6$ 日 \\
$11: 00 \sim 15: 00$
\end{tabular} & 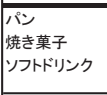 & \begin{tabular}{|l|}
-音楽演奏 \\
•アンケ調査
\end{tabular} & ·クルージング & & $\begin{array}{l}\text { 学園祭 } \\
\text { (11月4.5.6日) }\end{array}$ \\
\hline $\begin{array}{c}\text { 秋後半 } \\
11 \text { 月9·10日 } \\
16 \cdot 17 \text { 日 } \\
11: 00 \sim 15: 00\end{array}$ & 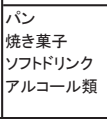 & \begin{tabular}{|l|} 
•クルージング \\
·アンケート調査
\end{tabular} & & & \\
\hline
\end{tabular}


表 4 「船カフェ」の来客数・売上

\begin{tabular}{|c|c|c|c|c|c|c|c|c|}
\hline & \multirow{2}{*}{ 日付 } & \multirow{2}{*}{ 天気 } & \multicolumn{2}{|c|}{ 気温 $\left({ }^{\circ} \mathrm{C}\right)$} & \multicolumn{2}{|c|}{ 船カフェ } & \multicolumn{2}{|c|}{ クルージング } \\
\hline & & & 最高 & \begin{tabular}{|l||} 
最低 \\
\end{tabular} & 来客数(人) & 売上(円) & 来客数(人) & 売上(円) \\
\hline \multirow{16}{*}{ 春 } & \begin{tabular}{l|l} 
4月14日 \\
\end{tabular} & \begin{tabular}{|l|l} 
晴 \\
\end{tabular} & 22.1 & \begin{tabular}{|l|l}
11.1 \\
\end{tabular} & 153 & 85,410 & & \\
\hline & 4月15日 0 金 & 晴 & 22.5 & 13.7 & 125 & 70,010 & & \\
\hline & \begin{tabular}{l|l|} 
4月16日 & 土 \\
\end{tabular} & 晴 & 24.6 & 12.9 & 220 & 122,970 & & \\
\hline & \begin{tabular}{l|l|} 
4月17日 \\
\end{tabular} & 晴のち曇 & 17.6 & 9.6 & 286 & 160,290 & & \\
\hline & \begin{tabular}{l|l} 
4月18日 & 月 \\
\end{tabular} & \multicolumn{5}{|c|}{ 定休日 } & & \\
\hline & \begin{tabular}{l|l|} 
4月19日 & 火 \\
\end{tabular} & 晴時々曇 & 18.1 & 7.3 & 119 & 55,670 & & \\
\hline & \begin{tabular}{l|l|l} 
4月20日 & 水 \\
\end{tabular} & \begin{tabular}{|l|l} 
晴のち曇 \\
\end{tabular} & 16.7 & 6.5 & 138 & 64,660 & & \\
\hline & 4月21日 6 & 晴のち曇 & 16.2 & 8.8 & 132 & 60,590 & & \\
\hline & \begin{tabular}{l|l|l} 
4月22日 & 金 \\
\end{tabular} & 曇 & 18.8 & 11.4 & 118 & 55,990 & & \\
\hline & 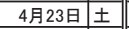 & 雨 & 17.9 & 14.8 & 32 & 20,230 & & \\
\hline & \begin{tabular}{l|l|} 
4月24日 \\
\end{tabular} & 晴 & 20 & 11.4 & 288 & 160,400 & & \\
\hline & \begin{tabular}{l|l|} 
4月25日 & 月 \\
\end{tabular} & \multicolumn{5}{|c|}{ 定休日 } & & \\
\hline & \begin{tabular}{l|l|} 
4月26日 & 火 \\
\end{tabular} & 晴 & 21 & 11.3 & 118 & 69,780 & & \\
\hline & \begin{tabular}{|l|l|} 
4月27日 \\
\end{tabular} & $\begin{array}{c}\text { 晴 } \\
\end{array}$ & 24.4 & 14.9 & 107 & 71,700 & & \\
\hline & \begin{tabular}{l|l|} 
4月28日 \\
\end{tabular} & 晴 & 24.8 & 14.3 & 125 & 88,450 & & \\
\hline & \multicolumn{4}{|c|}{ 小計 } & 1,961 & $1,086,150$ & & \\
\hline 夏 & \begin{tabular}{l|l} 
8月6日 & 土 \\
\end{tabular} & \begin{tabular}{|c|l} 
晴 \\
\end{tabular} & 32.3 & 26 & 658 & 190,070 & 190 & 別会計 \\
\hline \multirow{8}{*}{ 秋 } & \begin{tabular}{|l|l|} 
11月4日 & 金 \\
\end{tabular} & \begin{tabular}{c|c|l} 
晴 \\
\end{tabular} & 22 & 14.8 & 104 & 25,400 & 58 & 56,000 \\
\hline & \begin{tabular}{l|l} 
11月5日 & . \\
\end{tabular} & 晴 & 22.2 & 15.2 & 168 & 54,000 & 77 & 70,000 \\
\hline & \begin{tabular}{l|l} 
11月6日 & 日 \\
\end{tabular} & 曇時々雨 & 22.7 & 15.9 & 148 & 38,880 & 44 & 44,000 \\
\hline & \begin{tabular}{|l|l|} 
11月9日 & 水 \\
\end{tabular} & 曇 & 16.6 & 11.7 & 109 & 35,890 & 55 & 53,000 \\
\hline & \begin{tabular}{|l|l} 
11月10日 \\
\end{tabular} & 曇 & 16.2 & 11.9 & 60 & 26,250 & 32 & 32,000 \\
\hline & \begin{tabular}{|l|l} 
11月16日水 \\
\end{tabular} & 晴 & 15.8 & 9.7 & 63 & 27,650 & 15 & 15,000 \\
\hline & \begin{tabular}{|l|l|} 
11月17日 \\
\end{tabular} & 晴 & 19.7 & 9.5 & 65 & 34,420 & 38 & 38,000 \\
\hline & \multicolumn{4}{|c|}{ 小計 } & 717 & 242,490 & 319 & 308,000 \\
\hline \multicolumn{5}{|c|}{ 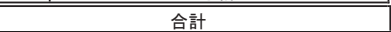 } & 3,336 & $1,518,710$ & 509 & 308,000 \\
\hline \multicolumn{9}{|c|}{ 刀収支結果 } \\
\hline \multicolumn{2}{|r|}{ 単位(円) } & & \multicolumn{2}{|c|}{ 春 } & \multicolumn{2}{|r|}{ 夏 } & \multicolumn{2}{|c|}{ 秋 } \\
\hline \multirow{3}{*}{ 売上 } & \multicolumn{2}{|l|}{ 船カフェ } & \multicolumn{2}{|c|}{$1,086,200$} & \multicolumn{2}{|r|}{190,070} & \multicolumn{2}{|r|}{242,490} \\
\hline & \multicolumn{2}{|l|}{ クルージング } & & 0 & \multicolumn{2}{|c|}{ 別会計 } & \multicolumn{2}{|r|}{308,000} \\
\hline & 計 & & & $, 086,200$ & & 190,070 & & 550,490 \\
\hline & 船代 & & & 162,930 & & 会計 & & 550,420 \\
\hline & カフェ原価 & & & 535,372 & & 120,224 & & 170,025 \\
\hline 古出 & 金券*1 & & & 0 & & 53,850 & & 0 \\
\hline 文出 & 広告費 & & & 0 & & |会計 & & 4,935 \\
\hline & 人件費 ${ }^{2}$ & & & 295,500 & & 0 & & 76,800 \\
\hline & 計 & & & 993,802 & & 174,074 & & 802,180 \\
\hline & "収支 & & & 92,398 & & $\begin{array}{l}15,996 \\
\end{array}$ & & $-251,690$ \\
\hline
\end{tabular}

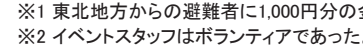

地方からの避難者に対して金券を配ったものの、利益が約 2 万円で あった。秋では、売上が約 24 万円であり、船代が春・夏より高かっ たため、損失は約 25 万円であった。

\section{3 小結}

「船カフェ」の全体的な結果として、来客数は 21 日間で合計 3,336 人、1 日平均 177 人であった。船着場を活用したふれあいの場にな っていたと思われる。

来客数は、天候に大きく左右される。日照時間が短く、気温が低 くなる秋は全体的に少なくなる。また、同時に開催されるイベント によって増減する。天候、季節、同時開催イベントに注意する必要 がある。支出では、船代が大きく、船代が安くなる時期に実施しな ければならない。以上のことを考慮すれば「船カフェ」は事業とし て成立すると言える。

\section{4.「船カフェ」の評価と効果}

本章では、「船カフェ」の来客者に実施したアンケート結果から、 「船カフェ」の評価と効果について明らかにする。

アンケート回答者の属性を図 5 に示す。

アンケートは来客数の 1 割を目処に収集した。限られたデータか らの推測になるが、各期間にばらつきがあるものの、幅広い年代を 集めていると言える。居住地は豊洲地区が約半分を占め、江東区外 も 4 分の 1 程度を占める。これは会社員がいるためと考えられる。

\section{1 「船カフェ」の評価}

「船カフェ」の評価に関するアンケート結果を図 6 に示す。

「船力フェ」については、ほぼ全てが「とても良い」「まあまあ良
い」であり、非常に好意的である。また、再度実施して欲しいとい う人がほとんどである。

\section{2 「船カフェ」の効果}

「船カフェ」の効果に関するアンケート結果を図 7 に示す。 船着場については、春から秋にかけて「知らない」が減少し、「知って いた」が若干増加した。また、「今回知った」が毎回 $12 \%$ 21\%であっ た。「船カフェ」は船着場の認知度を確実に高めていると言える。 運ルネ協議会については、春から秋にかけて「知らない」が大き

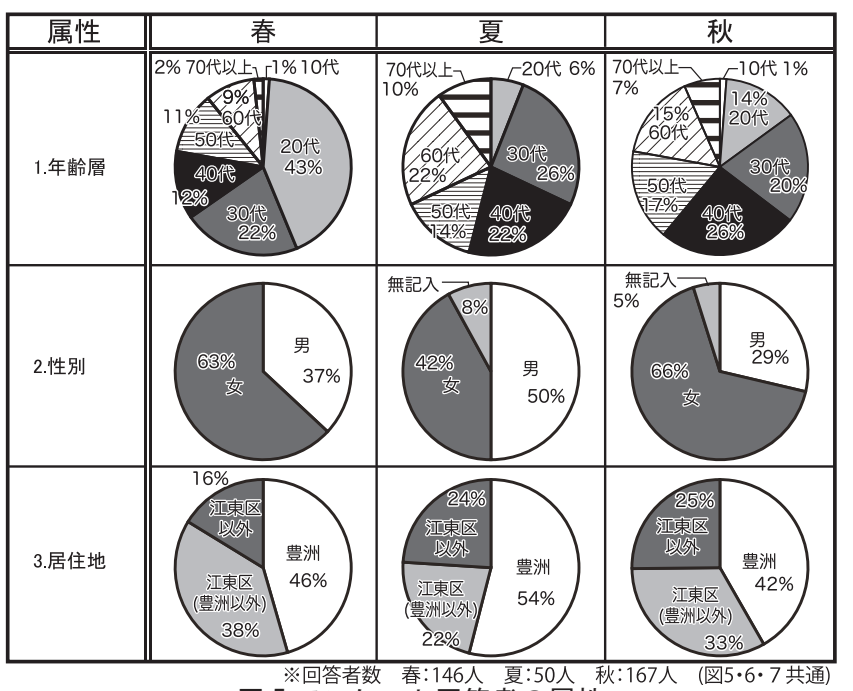

図 5 アンケート回答者の属性

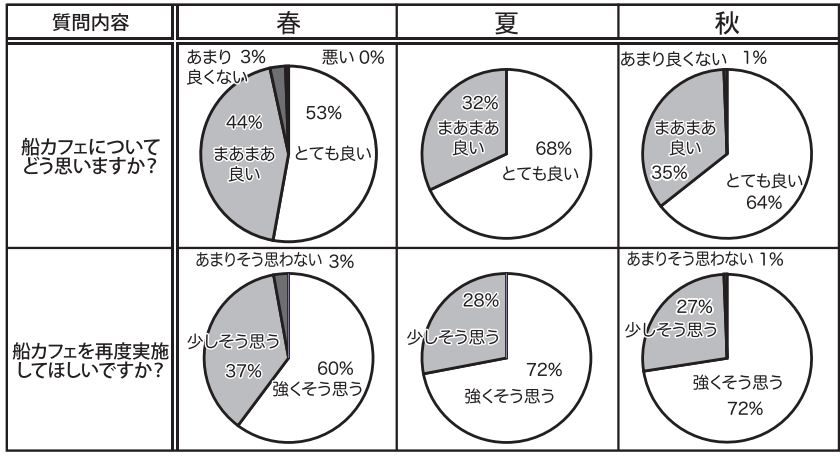

図 6 「船カフェ」の評価

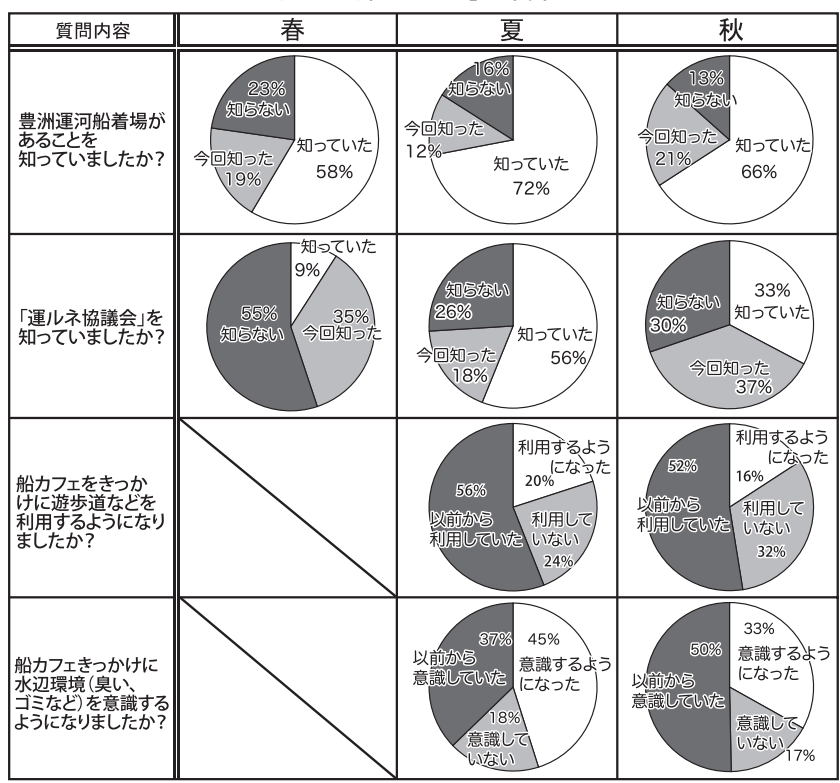

図 7 「船カフェ」の効果 
表 6 春の「船カフェ」の実施経緯と役割分担

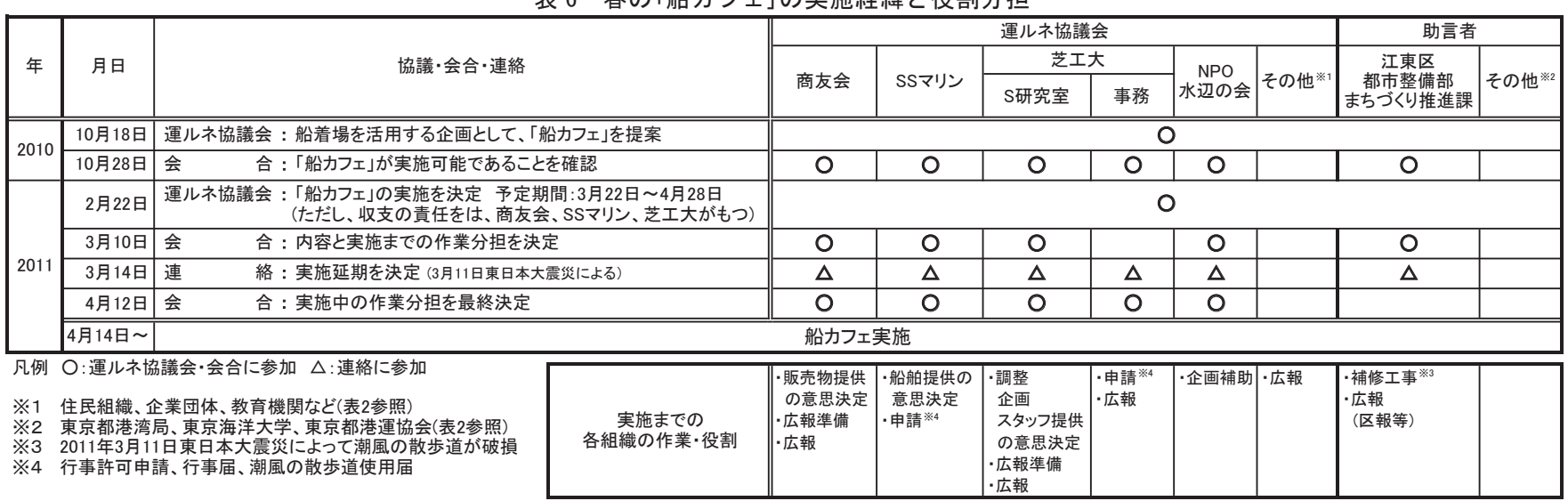

く減少した。反対に「知っていた」が大きく増加した。また、「今回 知った」が 18\%〜37\%あった。「船カフェ」は運ルネ協議会の認知度 を確実に高めていると言える。

遊歩道の利用については、「利用するようになった」が夏で $20 \%$ 、 秋で $16 \%$ であった。また、水辺環境への意識については「意識する

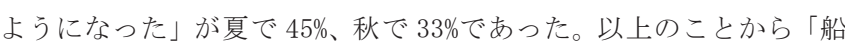
カフェ」は、水辺・運河への人々の関心を高めていると言える。

\section{3 小結}

「船力フェ」は幅広い来客者を集めていると言える。来客者のほ とんどが「船カフェ」に対して好意的であり、再度実施して欲しい と思っている。

また「船カフェ」は、船着場と運ルネ協議会の認知度を確実に高 めていた。更に、水辺・運河への人々の関心を高めていた。

以上のような「船カフェ」の評価と効果を確認することができた。

\section{5.「船カフェ」の実施体制と役割分担}

本章では、「船カフェ」を実施するまでと実施中の役割分担、そし て実施体制を明らかにする。準備段階にあたる実施するまでの経緯 については、最初に実施した春の「船カフェ」までの経緯に着目する。

\section{1 実施までの経緯}

春の「船力フェ」を実施するまでの経緯と役割分担を表 6 に示す。 2010 年 10 月 18 日「運ルネ協議会」で、船着場を活用する企画を 検討する中で「船カフェ」の提案があった。同年 10 月 28 日の会合 に地元商店会である「豊洲商友会協同組合」（以下：商友会）、クル ージング業者である「SS マリンサービス」（以下：SS マリン）、芝工 大 $\mathrm{S}$ 研究室・事務、「NP0 法人 江東区水辺に親しむ会」（以下：NP0 水辺の会)、「江東区都市整備部まちづくり推進課」（以下: 江東区都 市整備部)が参加し、「船カフェ」が実施可能であることを確認した。 その後、これら参加者が企画・準備を開始した。そして 2011 年 2 月 22 日「運ルネ協議会」で企画を確認し、収支の責任を、商友会、 SS マリン、芝工大が持つことを条件に「船カフェ」の実施を決定し た。その後、同年 3 月 10 日の会合に、商友会、SS マリン、芝工大 S 研究室、NP0 水辺の会、江東区都市整備部が参加し、内容と実施ま での作業分担を決定した。同年 3 月 14 日に、東日本大震災で、潮風 の散歩道が破損したこと等から、これまでの会合参加者間で連絡を 取り合い、実施延期を決定した。実施直前の同年 4 月 12 日には、商 友会、SS マリン、芝工大 S 研究室・事務、NP0 水辺の会が参加し、 実施中の作業分担を最終決定した。

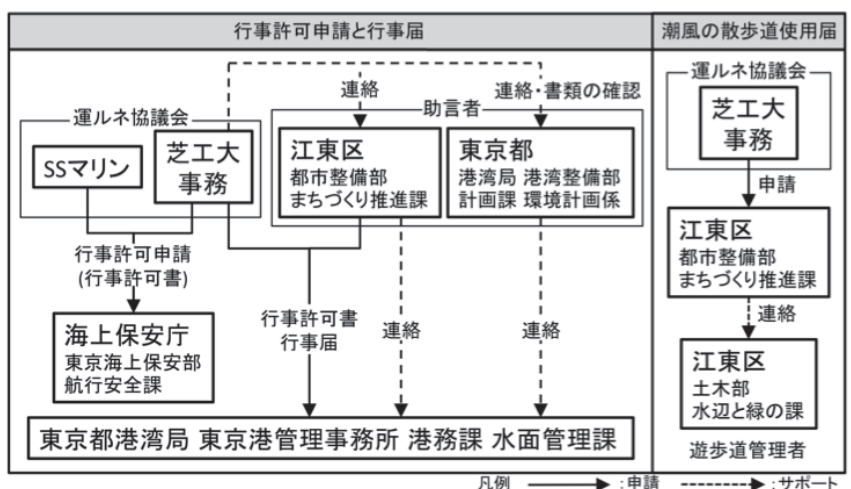

図 8 行事許可申請等の手続き

以上のように、商友会が販売物提供の意思決定、SS マリンが船舶提 供の意思決定、芝工大 $\mathrm{S}$ 研究室が調整・企画・スタッフ提供の意思 決定をした。NP0 水辺の会も企画補助を行った。また、SSマリンと 芝工大事務が申請を行った。商友会と芝工大 $\mathrm{S}$ 研究室が広報準備を 行った。幅広い組織が広報を行った。

\section{2 行事許可申請等の手続きと役割分担}

準備段階で行われた申請等の手続きについて、詳細に確認する。 申請等の手続きと役割分担について図 8 に示す。

「船カフェ」実施には、「行事許可申請」と「行事届」が必要である。 まず、SS マリンと芝工大事務が「海上保安庁東京海上保安部航行安 全課」に行事許可申請を行い、「行事許可書」を受理した。その後、 芝工大事務が江東区都市整備部と「東京都港湾局港湾整備部計画課 環境計画係」(以下: 東京都港湾整備部)に行事許可申請と「行事届」 の手続きの連絡をした。それを受けて、江東区都市整備部と東京都 港湾整備部が「東京都港湾局東京港管理事務所港務課水面管理係」

（以下：管理事務所）に連絡をした。そして、芝工大事務と江東区 都市整備部が管理事務所に行事許可書と行事届を提出した。

夏のテント販売には、「潮風の散歩道使用届」が必要である。潮風 の散歩道使用届は、芝工大事務が江東区都市整備部に申請をした。 それを受けて、江東区都市整備部が「江東区土木部水辺と緑の課」 に連絡した。

以上のように、芝工大事務と SS マリンが申請等の手続きを行い、 江東区都市整備部と東京都港湾整備部が、それを支援した。

\section{3 「船カフェ」実施中の作業分担}

「船カフェ」実施中の各組織の作業人員を表 7 に示す。

商友会が販売物管理と会計を行った。SSマリンが安全管理を行っ た。芝工大 S 研究室が調整、販売とアンケート調査を行った。東京 
表 7 「船カフェ」実施中の作業人員（延べ人数）

\begin{tabular}{|c|c|c|c|c|c|c|c|c|c|c|c|c|c|c|c|c|c|c|c|c|}
\hline & \multirow{3}{*}{$\begin{array}{l}\text { 組織 } \\
\text { 時期 }\end{array}$} & \multirow{2}{*}{\multicolumn{3}{|c|}{ 商友会 }} & \multirow{2}{*}{\multicolumn{3}{|c|}{ SSマリン }} & \multicolumn{6}{|c|}{ 芝工大 } & \multirow{2}{*}{\multicolumn{3}{|c|}{ NPO }} & \multirow{2}{*}{\multicolumn{3}{|c|}{$\begin{array}{c}\text { 東京 } \\
\text { 海洋大学 }\end{array}$}} & \\
\hline & & & & & & & & \multicolumn{3}{|c|}{ S研究室 } & \multicolumn{3}{|c|}{ 事務 } & & & & & & & \\
\hline & & \begin{tabular}{|l|l} 
春 \\
\end{tabular} & 夏 & 秋 & \begin{tabular}{|l|} 
春 \\
\end{tabular} & 夏 & 秋 & 春 & 夏 & 秋 & 春 & 夏 & 秋 & 春 & 夏 & 秋 & 春 & 夏 & & \\
\hline & 安全管理 & & & & 39 & \begin{tabular}{l|l}
3 & \\
3
\end{tabular} & 21 & & & & & & & & & & & & & 63 \\
\hline & 販売物管理 & $\mid 13$ & 2 & 14 & & & & & & & & & & & & & & & & 29 \\
\hline 業 & 会計 & 13 & 1 & 7 & & & & & & & & & & & & & & & & 21 \\
\hline 内 & $\begin{array}{ll}\text { 服売 } \\
\end{array}$ & & 3 & & & & & 36 & 9 & 25 & & & & & & & 29 & 9 & 9 & 120 \\
\hline 谷 & アンケート調査 & & & & & & & 13 & 2 & 7 & & & & & & & & & & 22 \\
\hline & 調整 & & & & & & & 13 & 1 & 7 & 13 & & & 13 & & & & & & 4 \\
\hline & 小計 & 26 & 6 & 21 & 39 & 3 & 21 & \begin{tabular}{|l|l}
62 & \\
\end{tabular} & 12 & 39 & 13 & 0 & \begin{tabular}{|l|}
0 \\
\end{tabular} & 13 & 0 & 0 & 29 & 9 & 9 & \\
\hline & 合計 & & 53 & & & 63 & & & 113 & & & 0 & & & 0 & & & 47 & & \\
\hline
\end{tabular}

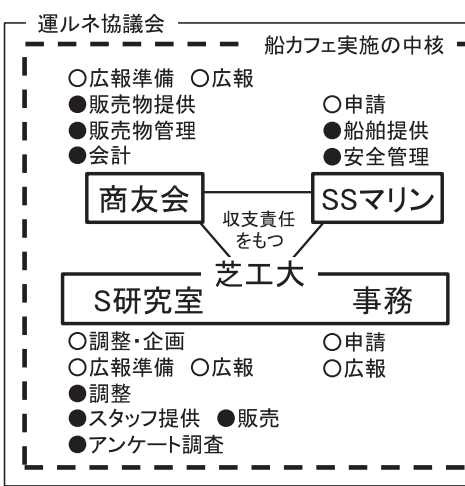

図 9 「船カフェ」の実施体制

\begin{tabular}{l} 
O企画 \\
我他の会員 \\
\hline
\end{tabular}

凡例 0 :䒠施までの作業

海洋大学 (以下: 海洋大) も販売を行った。春では、芝工大事務と NPO 水辺の会が調整を行った。

延べ人数は、芝工大 $\mathrm{S}$ 研究室が最も多く 113 人、次いで SS マリン が 63 人、商友会が 53 人であった。海洋大も 47 人と比較的多かった。 5.4 小結

実施までの経緯と役割分担、行事許可申請等の手続きと役割分担、 実施中の作業分担から明らかになった「船カフェ」の実施体制を図 9 に示す。

商友会が販売物提供、SS マリンが船舶提供、芝工大 S 研究室が調 整・企画・スタッフ提供、芝工大事務が主に申請等の手続きを行っ た。また、商友会が広報準備と当日の販売物管理・会計を、SS マリ ンが安全管理を、芝工大 $\mathrm{S}$ 研究室が広報準備と調整・当日の販売・ アンケート調查を行った。

以上のことから、運ルネ協議会会員の中で、商友会、SS マリン、 芝工大 $\mathrm{S}$ 研究室・事務の 3 者が「船カフェ」実施の中核だったと言 える。それぞれが各々の専門性を発揮することによって、船カフェ」 が基本的に実施可能となった。つまり、運ルネ協議会の中に、地元 商店会、クルージング業者、大学研究室と事務といった企画・調整・ 事務組織があり、それらが「船カフェ」実施の意思決定をすることが、 「船カフェ」を実施可能とする十分条件と言える。

また、NP0 水辺の会が企画を支援し、海洋大が販売を支援した。 運ルネ協議会の全会員が広報を行った。そして、江東区都市整備部 と東京都港湾整備部が申請等の手続きを支援した。以上のように、 運ルネ協議会と助言者になっている自治体等の連携により、最終的 に「船カフェ」が実施できた。このことも「船カフェ」を実施可能とす る十分条件と言える。

\section{6. まとめ}

本報告は、まちづくり協議会が主体となる水域活用の取組みの手 法を開発・普及寸ることを主眼とし、東京都江東区豊洲地区におい て、「船カフェ」を実施し、結果を報告すると共に、実施までの経緯
や実施体制について分析した。

まず、「船カフェ」の結果として以下のことを確認した。

(1)来客数は、21 日間で約 3,300 人であり、ふれあいの場となってい たと思われる。

(2)「船カフェ」は、天候、季節、同時開催イベント等を考慮すれば事 業として成立する。

(3)「船カフェ」は、幅広い来客者を集めていた。来客者のほとんどが 再度実施して欲しいと思っていた。

(4)「船カフェ」は、船着場と運ルネ協議会の認知度を確実に高めてい た。また、水辺・運河への関心を高めていたと言える。

さらに、「船カフェ」の実施可能となる十分条件について以下のこ とを明らかにした。

(1)住民組織等からなる運ルネ協議会が設立し、主体的に活動してい ること。

(2)船着場が存在または整備され、運ルネ協議会がその船着場を使用 できることを明記した管理協定を、運ルネ協議会、事務局、自治体 が締結すること。

(3)運ルネ協議会の中に、地元商店会といった販売物を提供できる組 織、クルージング業者といった船舶を提供できる組織、大学研究室・ 事務といった企画力を有し、調整・事務を担う組織があり、それら 組織が「船カフェ」実施の意思決定をすること。

(4)運ルネ協議会の会員と助言者になっている自治体等が「船カフェ」 実施を支援し、互いに連携をすること。

以上の知見を踏まえて、運ルネ協議会は、2012 年 4 月にも「船力 フェ」を実施した。今後も定期的に実施する予定である。

\section{謝辞}

本稿をまとめるにあたり、豊洲地区運河ルネサンス協議会の皆様 にご協力頂きました。ここに感謝の意を表します。

\section{注䣋}

注 1) 東京都港湾局の水域占用許可の規制緩和施策であり、芝浦地区と品川 浦・天王洲地区が 2005 年に指定されたのが最初で、次いで、朝潮地区、勝島・ 浜川・鮫洲地区が 2006 年に指定された。豊洲地区が 2009 年に指定された。 注 2) 豊洲地区運河ルネサンス協議会の配布資料と議事録、会合の配布資料と 議事録、「船カフェ」実施中にスタッフが記入した業務日誌である。

注 3) 商友会と SS マリン、芝工大事務に収支と行事許可申請等の手続きにつ いてヒアリング調查を行った。

注 4)一人ずつアンケートを配布し、その場で記入してもらい回収した。 注 5) 江東区が設計費として約 550 万円、設置工事費として約 5, 200 万円支出 し、芝工大が周辺環境整備費として 500 万円支出した。

注 6) ケーキは季節、アルコール類は芝工大や他のイベントとの調整で販売で きないこともあった。

注 7) 音楽演奏時には、場所を確保するために客席を減らすこともあった。 注 8) 2011 年 3 月 11 日東日本大震災の影響で、船代が安くなった。また、利 益の内の 5 万円は義援金として東北へ寄付した。

\section{参考文献}

1）畔柳昭雄: 人と水との係わりの構図から見た流域圈・都市の再生, 都市計 画 No. 278, pp. 49-52，2009.4

2）杉恵頼寧, 新上敏彦: 社会実験による水辺の再生〜広島市の京橋川オープ ンカフェ〜,都市計画 No. 278，pp. 37-40，2009.4

3）橋爪紳也：「水都」大阪物語-再生一の歴史文化的考察, 藤原書店 2011.3

[2012 年 5 月 16 日原稿受理 2012 年 8 月 17 日採用決定］ 